\title{
PENGKAJIAN KEPERAWATAN DI RUMAH SAKIT
}

\author{
Putri Syalsabila Manullang \\ psbila@gmail.com
}

\section{Latar Belakang}

Keperawatan merupakan suatu bentuk pelayanan profesional bersifat humanistik, menggunakan pendekatan holistik, dilakukan berdasarkan ilmu dan kiat keperawatan, berorientasi kepada kebutuhan objektif klien. Praktek keperawatan mengacu pada standar professional keperawatan dan menggunakan etika keperawatan sebagai tuntutan utama. Perawat dituntut untuk selalu melaksanakan asuhan keperawatan yang benar atau rasional (Nursalam, 2007).

Proses asuhan keperawatan merupakan tugas dan kewajiban seorang perawat dari pasien datang sampai pasien pulang, dimulai dengan pengkajian secara menyeluruh, kemudian menegakkan diagnosa keperawatan dari data pengkajian tersebut, serta melaksanakan intervensi, implementasi dan evaluasi keefektifan diagnosa awal yang sudah ditegakkan (Nursalam, 2007).

Rumah sakit dibedakan dari institusi kesehatan lain dari kemampuannya memberikan diagnosa dan perawatan medis secara menyeluruh kepada pasien. Perawat sebagai suatu profesi dapat mempertahankan dan meningkatkan mutu asuhan keperawatan maka jawabannya adalah dengan adanya standar. Standar merupakan level kinerja yang diinginkan dan yang dapat dicapai dimana kerja aktual dapat dibandingkan (Nursalam, 2011). Perawat sebagai suatu profesi yang merupakan bagian dari tim kesehatan bertanggung jawab membantu klien (Haryanto, 2007). Sumbangan yang diberikan perawat adalah melalui pelaksanaan proses keperawatan. Proses keperawatan adalah kerangka berpikir yang digunakan perawat untuk melaksanakan fungsi dan tanggung jawabnya secara mandiri. Tahap pertama dari proses keperawatan adalah pengkajian (Hidayat, 2002). Fase dari pengkajia meliputi: pengumpulan data, analisis data, pengelompokan data dan dokumentasi data (Haryanto, 2008).

Empat manfaat melakukan pengkajian yaitu kepuasan bagi perawat, menambah pengetahuan perawat, menentukan diagnosa pasien, dan mengetahui perkembangan pasien. Tiga partisipan mengungkapkan setelah melakukan proses pengkajian keperawatan, mereka merasakan kepuasan tersendiri dalam dirinya.

Pengkajian artinya adalah proses perolehan data. autoanamese adalah pengkajian langsung dan anamese adalah wawancara. Tujuan utama pengkajian adalah untuk mengetahui data pasien seakurat-akuratnya. Data yang harus di peroleh dalam pengkajian yaitu data dasar dan data fokus. Pengumpulan data adalah pengumpulan informasi tentang klien yang dilakukan secara sistematisnuntuk menentuan masalah-masalah, serta kebutuhan-kebutuhan keperawatan dan kesehatan klien. Pengumpulan informasi merupakan tahap awal dalam proses keperawatan. Dari informasi yang terumpul, didapatkan data dasar tentang masalah-masalah yang dihadapi klien. Selanjutnya data dasar tersebut digunaan untuk menentukan diagnosis keperawatan, 
merencanakan asuhan keperawatan, serta tindaan keperawatan untuk mengatasi masalah-masalah klien.

Keperawatan adalah unik karena fokusnya yang luas ke arah pemahaman dan penatalaksanaan kesehatan seseorang. Langkah pertama dari proses keperawatan,yaitu pengkajian, dimulai perawat dengan menerapkan pengetahuan dan pengalamanuntuk mengumpulkan data tentang klien. Seperti halnya para astronom menggunakan pengetahuan tentang galaksi untuk menggali melalui teleskop, perawat menerapkan pengetahuan ilmiah dan displin keperawatan untuk menggali dan menemukankeunikan klien dan masalah perawatan kesehatan personal klien. Dalam lingkungan perawatan kesehatan yang komlek ini perawat harusmampu menyelesaikan masalah kesehatan yang akurat, menyeluruh, dan gtepat Halini berarti bahwa perawat harus mampu menelaah informasi dalam jumlah yangsangat banyk untuk membuat penilaian kritis.

\section{Metode}

Penulisan kajian artikel ilmiah ini dibuat menggunakan model metode membaca atau literasi, menganalisa serta penelurusan ke berbagai referensi-referensi yang diantaranya yaitu jurnal ( 8 tahun terakhir), buku-buku teks, e-book, dan e-learning. Artikel ilmiah dalam kajian ini telah diatur dan disusun sesuai dengan topik yang mengacu pada sumber-sumber terkait yang berfokus pada pengkajian keperawatan dirumah sakit.

\section{Hasil}

Dari referensi dan sumber, hasil analisa yang didapatkan adalah Pengkajian merupakan tahap awal dan dasar dalam proses keperawatan. Pengkajian merupakan tahap yang paling menentukan bagi tahap berikutnya.Kemampuan mengidentifikasi masalah keperawatan yang terjadi pada tahap ini akanmenentukan diagnosis keperawatan. -leh karena itu, pengkajian harus dilakukandengan teliti dan cermat, sehingga seluruh kebutuhan perawatan pada klien dapatdiidentifikasi.Kegiatan dalam pengkajian adalah pengumpulan data. Pengumpulan dataadalah kegiatan untuk menghimpun informasi tentang status kesehatan klien. Statuskesehatan klien yang normal maupun yang senjang hendaknya dapat dikumpulkan,hal ini dimaksudkan untuk mengidentifikasi pola fungsi kesehatan klien, baik yangefektif optimal maupun yang bermasalah. Namun karena kepentingan praktis danadanya kendala keterbatasan waktu pengumpulan data dan dokumentasinya, makadibeberapa tempat kita menjumpai kebijakan yang memfokuskan item dalam format pengumpulan data dengan pertimbangan prioritas pengkajian atau pola fungsi terkaityang paling berpengaruh dengan gangguan sistem yang terjadi.

Seiring dengan Keputusan Menteri Kesehatan Republik Indonesia 836/MENKES/SK/2005, tentang Pedoman Pengembangan Kinerja ini dapat diterapkan diseluruh sarana pelayanan kesehatan khususnya Rumah Sakit dan Puskesmas di Indonesia, sehingga mempercepat pencapaian indikator standar pelayanan minimal kota dan pencapaian pelayanan kesehatan yang bermutu yang akhirnya akan terwujud Indonesia sehat 2025. Perawat sebagai suatu profesi dapat mempertahankan dan meningkatkan mutu asuhan keperawatan maka jawabannya adalah dengan 
adanya standar. Standar merupakan level kinerja yang diinginkan dan yang dapat dicapai dimana kerja aktual dapat dibandingkan (Nursalam, 2011).

Tujuan dari tahap pengkajian adalah untuk mengumpulkan informasi dan jugamembuat data dasar klien, mengidentifikasi dan mengenali masalah-masalah yang dihadapi klien. Tahap pengkajian merupakan dasar utama dalam meberikan asuhan keperawatan sesai dengan kebutuhan individu (klien). Oleh karena itu pengkajian yang benar, akurat, lengkap, dan sesuai dengan kenyataan sangat penting dalam merumuskan suatu diagnosis keperawatan dan dalam memberikan asuhan keperawatan sesuai dengan respon individu, sebagaimana yang telah ditentukan dalam standar praktik keperawatan dari American Nursing Association (ANA).

\section{Pembahasan}

Secara umum, pengkajian keperawatan adalah langkah awal dari melakukan proses keperawatan atau pemberian asuhan keperawatan. Pengkajian keperawatan dilakukan untuk mengetahui langkah- langkah dalam melakukan pengkajian keperawatan, baik secara umum maupun berdasarkan kehidupan sehari-hari. Pengkajian keperawatan tidak sama dengan pengkajian medis. Pengkajian medis difokuskan pada keadaan patologis, sedangkan pengkajian keperawatan ditujukan pada respon klien terhadap masalah-masalah kesehatan yang berhubungan dengan pemenuhan kebutuhan dasar manusia.

Pengkajian artinya adalah proses perolehan data. autoanamese adalah pengkajian langsung dan anamese adalah wawancara. Tujuan utama pengkajian adalah untuk mengetahui data pasien seakurat-akuratnya. Data yang harus di peroleh dalam pengkajian yaitu data dasar dan data fokus.

Tujuan Pengumpulan Data :

memperoleh informasi tentang keadaan kesehatan klien. untuk menentukan masalah keperawatan dan kesehatan klien.

Macam-macam data untuk pengkajian pada pasien dirumah sakit:

1. Sumber data Primer, Sumber data primer adalah data-data yang dikumpulkan dari klien, yang dapat memberikan informasi yang lengap tentang masalah kesehatan dan keperawatan yang dihadapinya. Contoh data yang didapat dari hasil wawancara langsung dengan klien.

2. Sumber data Sekunder, Sumber data sekunder adalah data-data yang diumpulkan dari orang terdekat klien (keluarga), seperti orang tua, saudara, atau pihak lain yang mengerti dan dekat dengan klien.

3. Sumber data lainnya, Catatan klien (perawatan atau rekam medis klien) yang merupakan riwayat penyakit dan perawatan klien di masa lalu.

Cara mendapatkan data yang baik:

1. jaga kerahasiaan

2. sebutkan nama 
3. jelaskan tujuan wawancara

4. jaga kontak mata

5. usahakan tidak tergesa

Cara pengkajian :

1. wawancara

2. observasi

3. pemeriksaaan fisik

4. rekammedik

5. pemeriksaan penunjang (misal fotoronsen)

Salah satu tahap dari proses keperawatan adalah tahap pengkajian. Pengkajian merupakan tahap yang sistematis dalam pengumpulan data tentang individu, keluarga, dan kelompok (Haryanto 2008). Pengkajian harus dilakukan secara komperhensif terkait dengan aspek biologis, psikologis, sosial, maupun spiritual. Pengkajian adalah pendekatan sistematis untuk mengumpulkan data dan menganalisanya (Manurung, 2011). Pengkajian adalah pemikiran dasar dari proses keperawatan yang bertujuan untuk mengumpulkan informasi atau data tentang pasien, agar dapat mengidentifikasi, mengenali masalah-masalah, kebutuhan kesehatan dan keperawatan pasien, baik fisik, mental, sosial dan lingkungan menurut Effendy (1995, dalam Dermawan, 2012).Pada tahap pengkajian, perawat mulai menerima dan mengidentifikasi masalah atau kebutuhan yang ada. Kebutuhan yang ada sering menjadi prioritas diatas kebutuhan potensial yang sering ditulis sebagai risiko. Pengkajian merupakan tahap awal proses keperawatan dengan mengumpulkan data klien melalui observasi, wawancara dan pemeriksaan fisik. Pengkajian yaitu mengumpulkan data, analisa data untuk mencapai kesimpulan.

Pengkajian dengan pendekatan teori model merupakan penggunaan format data dasar dengan berdasar pada konsep teori model keperawatan yang sudah di terima secara luas atau berdasar pada standar praktik. Konsep-konsep teori tersebut diantaranya seperti pola kesehatan fungsional dari Gordon (1994), Model Self care dari Dorothea Orem, Model Promosi kesehatan dari Pander (1996) juga standar pengkajian Nyeri Akut dari Agency For Health Care Research And Quality (1992).

Kegiatan dalam pengkajian adalah pengumpulan data. Pengumpulan dataadalah kegiatan untuk menghimpun informasi tentang status kesehatan klien. Statuskesehatan klien yang normal maupun yang senjang hendaknya dapat dikumpulkan,hal ini dimaksudkan untuk mengidentifikasi pola fungsi kesehatan klien, baik yangefektif optimal maupun yang bermasalah. Namun karena kepentingan praktis danadanya kendala keterbatasan waktu pengumpulan data dan dokumentasinya, maka di beberapa tempat kita menjumpai kebijakan yang memfokuskan item dalam format pengumpulan data dengan pertimbangan prioritas pengkajian atau pola fungsi terkaityang paling berpengaruh dengan gangguan sistem yang terjadi. Proses pengkajian meliputi langkah-langkah sebagai berikut 
1. Pengumpulan data secara sistematis.

2. Verifikasi data.

3. Organisasi data.

4. Interpretasi data.

5. Pendokumentasian data.

Pengetahuan merupakan faktor dominan dalam mencapai tingkatan keterampilan tertentu. Pengetahuan yang baik akan menjadikan individu lebih mudah mengembangkan keterampilan dengan latihan-latihan yang (Notoatmodjo, 2014). Hasil kerja dapat dicapai secara maksimal apabila individu mempunyai kemampuan dalam mendayagunakan pengetahuan dan keterampilan.

Berdasarkan hasil penilaian pengetahuan perawat tentang pengkajian komprehensif meliputi biopsikososiospiritual, sebagian besar masih kurang menguasai tentang pengkajian komprehensif. Adapun hasil penilaian keterampilan perawat mengkaji kebutuhan klien dari 16 point yang tercantum dalam lembar evaluasi tentang mengkaji kebutuhan klien, sebagian besar responden masih kurang terampil dalam mengkaji kebutuhan klien.

Menurut Dessler (2015) mengemukakan bahwa, "Pelatihan (training) berarti memberikan kepada karyawan baru atau karyawan yang ada keterampilan yang mereka butuhkan untuk melakukan pekerjaan mereka. Pelatihan sangat penting, jika karyawan yang berpotensi tinggi sekalipun tidak mengetahui apa yang harus dilakukan dan bagaiman melakukannya, mereka akan berimprovisasi atau tidak melakukan sesuatu sama sekali”.

Seorang perawat harus mempunyai pengetahuan dan keterampilan yang baik dalam mengkaji kebutuhan klien untuk menjalankan pengkajian komprehensif. Pengetahuan dan keterampilan perawat bisa saja menurun seiring berjalannya waktu dan perkembangan keilmuan, oleh karena itu perlu dilakukan pelatihan untuk meningkatkan kualitas perawat. Ketika dilakukan pelatihan hendaknya lebih menekankan pada pengkajian komprehensif dan ketrampilan mengkaji kebutuhan klien mengingat pada penelitian ini perawat masih kurang menguasai akan dua hal tersebut.

Faktor-faktor penghambat pelaksanaan proses pengkajian keperawatan yaitu kurangnya kemampuan perawat mengumpulkan data pengkajian yang komperhensif, enggan mengkaji, beban kerja yang tinggi, dan mengkaji itu memakan waktu. Dua partisispan mengungkapkan bahwa penghambat terlaksananya proses pengkajian keperawatan adalah kurangnya kemampuan perawat.

Proses keperawatan ini diperkenalkan pada tahun 1950-an sebagai proses yang terdiri atas tiga tahap : Pengkajian, perencanaan dan evaluasi yang didasarkan pada metode ilmiah pengamatan, pengukuran, pengumpulan data dan penganalisaan temuan. 
Kajian selama bertahun-tahun, penggunaan dan perbaikan telah mengarahkan perawat pada pengembangan proses keperawatan menjadi lima langkah yang konkret (pengkajian, identifikasi masalah, perencanaan, implementasi dan evaluasi) yang memberikan metode efisien tentang pengorganisasian proses berfikir untuk pembuatan keputusan klinis.

Pada Era BPJS-JKN (sekarang puskesmas adalah fasilitas kesehatan tingkat 1 atau kata lain pintu gerbang pertama untuk pelayanan kesehatan untuk rujukan ke fakes selanjutnya). Apabila terjadi ketidaklengkapan dalam pengkajian perawat dan ketidaktepatannya akan berdampak pada ketidaktepatan diagnosis yang ditegakkan, selanjutnya rencana intervensi tidak sesuai bahkan dapat mengancam keselamatan pasien. Asuhan keperawatan adalah asuhan professional, perawat harus melakukan secara baik yaitu secara kode etik dan benar sesuai standar praktik dan standar asuhan keperawatan.

\section{Penutup}

a. Kesimpulan

Pengkajian keperawatan adalah langkah awal dari melakukan proses keperawatan atau pemberian asuhan keperawatan. Pengkajian keperawatan dilakukan untuk mengetahui langkah- langkah dalam melakukan pengkajian keperawatan, baik secara umum maupun berdasarkan kehidupan sehari-hari.

b. Saran

Seorang perawat wajib melakukan pengkajian kepada pasien dirumah sakit sesuai dengan aturanaturan yang telah ditetapkan beserta langkah-langkah dalam melakukan pengkajian kepada pasien.

\section{DAFTAR PUSTAKA}

Achmadi, L., dkk. (2015). Gambaran tingkat pengetahuan perawat dalam penerapan standar asuhan keperawatan di ruangan rawat inap interna RSUD Datoe Binangkang. E-jurnal keperawatan, 3(3).

Carpenito, Ll. (2007). Diagnosa Keperawatan. Jakarta: EGC.

Dahlan, M. (2004). Statistik Untuk Kedokteran dan Kesehatan. Jakarta: Salemba Medika.

Hidayah, N. (2014). Manajemen Model Asuhan Keperawatan Profesional (MAKP) Tim Dalam Peningkatan Kepuasan Pasien di Rumah Sakit. Jurnal Kesehatan, 7, 410-426.

Kartikasari, Fitriana, Yani, Achir, Azidin, dan Yustan. (2020). Pengaruh pelatihan pengkajian komprehensif terhadap pengetahuan dan keterampilan perawat mengkaji kebutuhan klien di puskesmas. Jurnal Keperawatan Suaka Insan, Volume 5 Edisi I, Juni 2020.

Nursalam. (2008). Proses dan Dokumentasi Keperawatan. Jakarta: Salemba Medika. 
Potter, Patricia A (2005). Buku ajar fundamental keperawatan: konsep, proses, dan praktik. yogyakarta: Buku kedokteran EGC.

Simamora, R. H. (2019). Development of Guidelines for Applying appropriate Patient Identification to Achieve Patient Safety Goal

INC2019 12th International Nursing Conference. 2019.10455 - 455 (1 pages)UCI(KEPA) : I410ECN-0101-2019-512-001224337.

Simamora. R. H. (2008) The correlation of ward chief's giving direction and command and the performance of on-duty nurses at Jember dr. Subandi general hospital inpatient wards. Jurnal Administrasi dan Kebijakan Kesehatan, (https://fkm.unair.ac.id/jurnal-administr).

Supratti dan Ashriady. (2016). Pendokumentasian standar asuhan keperawatan di rumah sakit umum daerah MAMUJU, INDONESIA. Jurnal Kesehatan MANARANG, Volume 2, Nomor 1, Juli 2016.

Wiwin, Winani, dan Hendri. (2019). Perilaku Caring Perawat dalam Memberikan Asuhan Keperawatan di Salah Satu RS di Kabupaten Indramayu. Jurnal Keperawatan Profesional (JKP), Volume 7, Nomor 2 Agustus 2019.

Wulandini, Krianto, dan Priwahyuni. (2016). Faktor-faktor yang berhubungan dengan pendokumentasian asuhan keperawatan di rumah sakit jiwa. NERS JURNAL KEPERAWATAN,Volume 12, No.2, Oktober 2016, (Hal.131-142). 